\title{
Can a Kurd be a Turk? Clashing National Identities in Anatolia
}

\author{
Shengpeng Shi ${ }^{1, a}$
}

\author{
${ }^{1}$ International College Beijing, China Agricultural University, Beijing 100083, P.R. China \\ ashengpeng.shi@ucdenver.edu
}

Keywords: Nationalism, secularization,assimilation, Mustafa Kemal

\begin{abstract}
This paper aims to explore the clash of national identities between Kurds and Turks. Essentially, the author argues that, in this enduring clash of the national identities, the official Turkish nationalist policies separated the Kurds from Turkey ideologically, culturally and politically and even destroyed the Kurdish aspirations of autonomy. These very same policies that were supposed to create unity and assimilation have instead caused discord, strife and resentment, which offers a profound challenge to Turkish national identity.
\end{abstract}

\section{Introduction}

The conflict between Kurdish nationalists and the Turkish government continues to be in the headlines on a daily basis. This long-standing and deadly confrontation has the potential to have serious repercussions in regional Middle Eastern politics and on the broader international stage as well. The Kurds are a distinct people. They are the largest nation in the world that does not have independence or their own nation-state. Instead, they are spread over 4 countries: Iran, Iraq, Syria and Turkey. The Kurdish century-old struggle for independence demonstrates the limitations of nationalist aspirations if the movement is systematically crushed by a hegemonic power. In this enduring clash of the national identities, the official Turkish nationalist policies, intended to create unity and assimilation have, in fact, separated the Kurds from Turkey ideologically, culturally and politically and even destroyed the Kurdish aspirations of autonomy.

\section{Unkept promises}

The roots of this conflict lie in the ashes of World War I. With the establishment of the Republic of Turkey in 1923, the Ataturk government, in stark contrast with the pluralistic and multi-cultural practices of the Ottoman Empire, systematically forged a new, modern Turkish identity. Under the six principles of Kemalism, this new state sought to develop a modern nation-state based on a specific ethno-nationalism

At the same, after the defeat of the Ottoman Empire in World War I, the Kurds found themselves in a prime position to seek independence. The 1919 Treaty of Sevres substantiated Kurdish claims for an independent nation state by stating that the Kurds could establish autonomous regions and independent states in areas to the east of the Euphrates river south of Armenia, east of Syria, and areas to the north of Iraq. This area is commonly known as Kurdistan, the land of the Kurds. The Sevres Treaty was the only document that addresses the autonomy or independence of Kurds by an international body. It has therefore served as the main legal basis for the Kurdish quest to establish an independent state. However, the nascent Turkish Republic had other ideas. Mustafa Kemal "Ataturk", the " father of the Turkish state", refused to accept the Treaty of Sevres. The Turks were willing to resist the treaty militarily. Yet, the war-dreary superpowers of Europe had little interest to wage a war against the Turks in the name of Kurdish nationalism. The determination of the Turks to ensure Anatolia to themselves eventually resulted in the Treaty of Lausanne in July 1923, which replaced the Treaty of Sevres. The Lausanne treaty did not mention the issue of Kurdish autonomy or independence. Kurdish hopes were dashed. The international community did not follow through with their promises of a new Kurdistan state. Yet how would they fare in the new Turkish Republic?

The Sevres treaty had opened up a Pandor's box. The Kurds became passionate and eager to live in their own nation-state and govern themselves where they could speak the Kurdish language, 
practice their form of Islam and continue their unique cultural practices. What was more, the Kurds had witnessed that both Italians and Greeks, who used to live in the Ottoman Empire had already gone back to their own nations and continued with their unique lives, religiously and culturally. However, the re-signed "Treaty of Lausanne" ruined the chance of Kurdish independence. It ignored the issue of Kurdish autonomy or independence. Somewhat, ironically, this silence only hardened Kurdish resolve. This lack of recognition made the Kurds more inspired and passionate about their independence. The only way forward seemed to be complete separation from the Turkish Republic. Yet this step proved to be difficult and problematic since the new leaders of Turkey were adamantly against Kurdish aspirations and did everything in their considerable political power to prevent any form of momentum for the Kurdish nationalists. The government had significant tools at their disposal and was willing to deploy those tools at will [1].

\section{Secularization: eliminating the last ideological tie}

When the Turkish Republic was established, unlike the pluralism of the Ottoman Empire, the Turkish government emphasized that Turkey was a modern nation-state based on a homogeneous ethnic nationalism. Kemal had promised to give the Kurds autonomy after Turkey's independence. Yet he did not live up to his promise. Instead, he started the process of radical secularization. In 1924, with the permission of Kemal, the Grand National Assembly deposed the Caliph, abolished the Caliphate, and banished all members of the house of Osman from Turkey. (Ahmad, 1993) This action was the prelude to the program of radical secularism in Turkey. This policy was challenging to Kurdish sense of self because religion is one of the most important components of Kurdish identity. During the Ottoman era, Sunni Islam was a unifying factor between Kurds and Turks yet now this connection was being contested. Furthermore, Kemal resolved to replace religious loyalties and fealties with a Turkic centric-national identity. He promoted a new motto "Ne mutlu Türküm diyene", which meant how happy is he or she who calls himself or herself a Turk. This motto was intended to replace the traditional slogan "Long live the Sultan," or "Long Live the Caliph" which could theoretically unite people together of different ethnicities together. Both the changed policy and the motto intended to force the Kurds to be secularized. Ataturk essentially thrust his version of Turkishness upon them.

As previously stated, Sunni Islam was one common tie between the Kurds and Turks. The process of secularization, inherent in Kemalism, eliminated this common ground. For Ataturk, it was important that secularity definite the political space. Yet for the more traditional minded Kurds, they were more inclined to promote some form of religion in the public sphere. Generally speaking, the Kurds were relatively more conservative in religious matters and closely adhered to their traditional practices instead of embracing a modern secular outlook. Therefore, secularization became the oil on the fire stoking Kurdish nationalism. The secularization process only served to magnify the differences between Kurds and Turks.

In this context, the first armed Kurdish rebellion against secular republican Turkey took place in 1925. Kurdish tribal leader Sheikh Said launched an uprising, calling for the overthrow of the secular government through jihad and the restoration of the caliphate system. This rebellion kicked off the war between the Kurds and the Turkish government. However, Turkish armed forces succeeded in quickly suppressing the resurrection. From then on, the Turkish government often took violent measures to suppress Kurdish rebellions, such as the Ararat revolt of 1930 and the Dersim rebellion of 1937, and it also continued its modern secular program (Olson, 2000) [2]

\section{Assimilation: backfiring on Kurdish Nationalism}

The fighting of Kurdish rebels, in the name of a new form of Turkish nationalism, fueled the competition of two different national identities. The Turks forced the Kurds to accept this ideology and became modern, secular and patriotic Turks. This assimilation by gun-point was extremely offensive to the Kurds and was bound to backfire.

From the Turkish perspective, Kemalism emphasized that the shared language, and shared values, 
defined as a common history, would inevitably lead to a mutually beneficial future. The intellectual source of this ideology could be traced back to Jean-Jacques Rousseau's political philosophy of the General Will, which considers society as a whole. The General Will is a will different from any individual or group of individual wills. The General Will was the result of the goodness and wisdom of each individual person that society was coordinated by the general will. Accordingly, Atatürk stated that the Kemalist nationalism was the product and the representation of the individual wills of any person in society. It was always a force of the good and the just. Thus, Kemalist nationalism was independent, infallible, and inviolable, which represented the entire people's interests and everyone within the nation would benefit from this reformation. By this logic, everyone, including the Kurdish population, needed to follow and obey this general will of Kemalism.

To be specific, Turkish government accelerated its policy of assimilation in the Kurdish region. It revoked all maps and official documents containing the names of "Kurdish" and "Kurdistan", disapproving the ethnic status of Kurds. And it renamed Kurds as the "mountain Turks" and deprived them of their language and cultural rights, and imposed martial law and military control for a long time in areas inhabited by Kurds. The theoretical source of this policy was the Kemalism that aimed to create a nation state from the remnants of the multi-religious and multi-ethnic Ottoman Empire. As Mustafa Kemal Atatürk mentioned, in the administration and defense of the Turkish Nation; national unity, national awareness and national culture are the highest ideals that we fix our eyes upon. In other words, the Turkish government tended to force every citizen in Turkey including the Kurds to conform to the same national identity and culture.

The Kemalist reformation was not a democratic process with the Kurds' agreements but the dictatorial demands for the Kurds. The Kurdish ethnic difference, cultural aspirations and religious beliefs had been systematically ignored, denied or suppressed. According to the Turkish constitution, Kurds were the official citizens that they had to give up their own national identities to be "modernized" and "secularized". However, the fact that the Kurds still lived in their own communities, spoke a completely different language and, tended to lead religious lives contributed to making any process of assimilation problematic. The resistance to becoming Turkish contributed to the more isolated and weakened conditions among the Kurds. They became secluded politically and economically. In other words, their Kurdishness became a barrier to Turkishness. Though the assimilation policies were supposed to promote unity and the idea of one people, in effect it made the Kurds second-class citizens in the Republic of Turkey since they could never be considered as "real" Turks.

The Kemalist nationalist policies were intended to force the Kurds to change their identity, to modernize and even to love the nation of Turkey. However, this forced love contributed to the more serious ethnic hatred and even strengthened Kurdish nationalism itself. Ironically, Turkish nationalism contributed to the realization of Kurdish nationalism. On the contrary, their own national identity was strengthened. When Turks emphasized the awareness, unity and pride of Turkish nation, the differences between Turks and Kurds were also highlighted. The model of Kemalist nationalism helped Kurds to notice, distinguish and realize their own unique language, culture and identity. Thus, Turkish nationalism, which aimed to assimilate the Kurds, excluded the Kurds in a more serious way. The Kurds became desperate that the hostility towards Turks was strengthened, the desire of being independence was promoted and the conflict between these two different national identities was spiraled [2][3].

\section{The radical reactions of the PKK}

Ever since the 1920s, the Kurdish people have resisted forced Turkish assimilation. This struggle has taken on many different forms as a diverse set of political parties developed among the Kurds. The Kurdish Workers Party (PKK) was established by Abdullah Ocalan in 1978 is recent prominent example. The organization adopted a communist ideology, but later the aim of the organization was committed to the foundation of an independent Kurdish state in south-eastern Turkey and Syria (Teymur \& Cindy, 2008). It was a radical and unique political party that it openly espoused a separatist goal of complete independence unlike other Kurdish organizations in Iraq and Iran that it 
considered the only autonomy as realistic with the vision of the pan-Kurdish, seeking the creation of a greater united Kurdistan. On the other hand, it was heavily by a Marxist-socialist revolutionary vision that the Kurdish must be recognized. The PKK intended to achieve the autonomy and independence through the revolution, which meant utililizing military approaches and even the terrorist approach if necessary. They called themselves "Kurdistan revolutionaries". In November 1978, the party member of the PKK held a major declaration, and published it named the Kürdistan Devrimin Yolu, which formally entered the period of the armed struggle for independence. However, in 1980, the PKK was banned by the Turkish government on the grounds of attempting to split the country, and it moved its activities underground. Since 1980s, the PKK has launched several armed guerrilla struggles, and its influence had been developing rapidly in the southeastern part of the country and in the eastern provinces. For example, in 1984, the Kurdish guerrillas attacked the town of Eruh, in Siert and Emdinli, in Kali Kali Province, and officially declared the people's war against the "Turkish fascist regime".

So far, the Kurdish issue has become a serious threat to Turkey's national security and unity within the Turkish territory. The confrontation between the PKK and Turkish government has caused numerous fatalities and contributed to a ongoing refugee crisis,. The PKK kept organizing the national movements and fighting for their independence that they refused to return to peace talks unless the Turkish government accepts their demands for democratic autonomy, while Turkish Special Forces carried out many organizations in the region and killing hundreds of PKK members. The Turkish government considers the PKK a terrorist organization and claim that they bear responsibility for civilian Turkish casualties. Yet one person's terrorist is another's freedom fighter. From the Kurdish perspective, these were nationalist political attacks at legitimate targets on their occupationary force. . In this violent ethnic conflict, there have been victims on both sides.. The Kurds maintain that their resort to violence was their last resort and a logical outcome of the Kemalist policies demanding assimilationist policies that separated the Kurds and forced them to become radical [4][5].

\section{Conclusion}

The Treaty of Lausanne, which did not mention the promise of Turkish independence, was the start of this century-long conflict that Kurds. The dashed hopes of Kurdish independence made them start to fight for the national identity of being the Kurds. During the 1930s, the secularization policy of Kemalism eliminated one of the most ties and similarities, the Sunni religion, between Kurds and Turks. Refusing to be secularized, Kurds started the first step of their own national movement. The Kemalisist nationalism and its assimilation policies contributed to the more serious ethnic hatred and even strengthened Kurdish nationalism itself. And the emergence of the PKK was the outcome of strengthened Kurdish nationalism and Kurds decided to fight for the national independence through the radical and revolutionary approaches. Thus, the conflicts between Kurds and Turks are the clash of the national identities. With the language differences, cultural variances and distinct historical memories, a Kurd cannot and will never be a Turk no matter how hard the Turkish government seeks to prove otherwise.

Therefore, it is vital to sort out its ethnical problems of these two strong nationalisms from both sides [6]. From Kurds' perspective, there are no faults that they intend to achieve the autonomy and independence after such a long time of homelessness and chaos. And the Kurdish nationalism itself is not questionable, however, the approaches are needed to rethink. The violent approaches might only contribute to the strengthened hostile and the terrorist label rather than Substantive progresses. From the Turkish perspective, over the past decades, Turkey has already achieved modernization and secularization and it has become the role model for the Middle East countries to make economic and political progresses. However, the problem is that Turkey is still an exclusive nation that does not respect the claims of the other ethnic groups. Turkish nationalism is like a barrier that separates the Kurds and destroys their aspirations of autonomy. Thus, it is crucial for Turkish government to reconsider its national and ethnic polices and whether the hegemonic ideology can truly help them to become one of the most developed countries. Whenever Turkey embraces all 
ethnic groups and is more inclusive, this century-old ethnic conflict would be solved and Turkey would truly on the path of their former glories. Undoubtedly, without military confrontations, it would develop better. Therefore, it is high time Turkey gives individual and group rights for Kurds.

\section{References}

[1] F. Ahmad, The making of modern Turkey, New York: Routledge, 1993.

[2] M.M. Gunter, The Kurds in Turkey: a political dilemma, Westview: Boulder CO, 1990.

[3] G. Fuller, The fate of the Kurds, Foreign Affairs, vol. 72(2), pp. 108-121, 1993.

[4] Y. Hanefi, PKK terrorism in Turkey, Open Journal of Political, Science, vol. 06, pp. 310-315, 2016.

[5] S. Teymur and J.S. Cindy, The PKK: a decades-old brutal Marxist-Leninist, Separatist Terrorist Organization, Washington: Turkish Institute for Security and Democracy, 2008.

[6] G. Harris, Ethnic conflict and the Kurds. The Annals of the American Academy of Political and Social Science, vol. 433, pp. 112-124, 1977. 